\title{
Assessing the relative appropriateness of the credit management policies of South African universities of technology
}

\begin{tabular}{|c|c|}
\hline \multicolumn{2}{|c|}{$\begin{array}{l}\text { Authors: } \\
\text { Gauda J. Maseko }{ }^{1} \text { (D) } \\
\text { Merwe Oberholzer }^{2} \text { (D) } \\
\text { Susanna L. Middelberg }{ }^{1} \text { (D) }\end{array}$} \\
\hline \multirow{2}{*}{\multicolumn{2}{|c|}{$\begin{array}{l}\text { Affiliations: } \\
{ }^{1} \text { School of Accounting } \\
\text { Sciences, Faculty of Economic } \\
\text { and Management Sciences, } \\
\text { North-West University, } \\
\text { Potchefstroom, South Africa }\end{array}$}} \\
\hline & \\
\hline \multicolumn{2}{|c|}{$\begin{array}{l}{ }^{2} \text { WorkWell Research Unit, } \\
\text { Faculty of Economic and } \\
\text { Management Sciences, } \\
\text { North-West University, } \\
\text { Potchefstroom, South Africa }\end{array}$} \\
\hline \multicolumn{2}{|c|}{$\begin{array}{l}\text { Corresponding author: } \\
\text { Merwe Oberholzer, } \\
\text { merwe.oberholzer@nwu.ac.za }\end{array}$} \\
\hline \multicolumn{2}{|c|}{$\begin{array}{l}\text { Dates: } \\
\text { Received: } 25 \text { Feb. } 2019 \\
\text { Accepted: } 24 \text { May } 2019 \\
\text { Published: } 26 \text { Sept. } 2019\end{array}$} \\
\hline \multicolumn{2}{|c|}{$\begin{array}{l}\text { How to cite this article: } \\
\text { Maseko, G.J., Oberholzer, M. \& } \\
\text { Middelberg, S.L., 2019, } \\
\text { 'Assessing the relative } \\
\text { appropriateness of the credit } \\
\text { management policies of } \\
\text { South African universities of } \\
\text { technology', Journal of } \\
\text { Economic and Financial } \\
\text { Sciences } 12(1) \text {, a } 460 . \\
\text { https://doi.org/10.4102/jef. } \\
\text { v12i1.460 }\end{array}$} \\
\hline \multicolumn{2}{|c|}{$\begin{array}{l}\text { Copyright: } \\
\text { (C) 2019. The Authors } \\
\text { Licensee: AOSIS. This } \\
\text { is licensed under the } \\
\text { Creative Commons } \\
\text { Attribution License. }\end{array}$} \\
\hline \multicolumn{2}{|l|}{ Read online: } \\
\hline 回要回 & $\begin{array}{l}\text { Scan this QR } \\
\text { code with your } \\
\text { smart phone or } \\
\text { mobile device } \\
\text { to read online. }\end{array}$ \\
\hline
\end{tabular}

Orientation: The study explores credit management on the South African higher education landscape in the context of the institutional theory.

Research purpose: To calculate a best practice frontier to assess the extent to which universities' credit management policy as an institutional resource is appropriate for its environment.

Motivation for the study: The study was undertaken to investigate how the institutional environment influences the development of formal university structures.

Research design, approach and method: A parallel mixed-method research design was followed to collect both qualitative data and quantitative data: document analysis to assess five universities of technology's credit management policies and quantitative data testing 1392 senior students' perspectives on the credit management policies of these five universities of technology.

Main findings: The lesson learnt from this study is that the more aggressive the credit management policy, the more the students rated it as appropriate (fair, understandable and accurate). Furthermore, contrary to extant literature, no evidence was found that a stringent or aggressive credit management policy is experienced as rigorous.

Practical/managerial implications: Universities of technology may apply aggressive credit management policies without the fear that they will be perceived as rigorous.

Contribution/value-add: Policymakers should note that students desire a credit management policy that: (1) is well communicated to them; (2) encourages them, by granting discounts, to do early settlements of debt; (3) is strictly implemented; and (4) is strict with regard to the collection and recovery of (deferred) debt.

Keywords: accounts receivables; aggressive and conservative credit management; institutional theory; universities of technology; South Africa; lenient; moderate and stringent policies.

\section{Introduction}

The paradigm that the institutional environment can strongly influence the development of formal structures in an institution was central to this study. As such, the study investigated the credit management policy of universities of technology (UOTs) in South Africa and their students' perception of the appropriateness of those policies. Credit management (accounts receivable) enables institutions to make proper financial decisions (Ramiah et al. 2016). Ngugi (2015) identifies five steps in managing accounts receivable, namely (1) determining to whom to extend credit, (2) establishing a payment period, (3) monitoring collections, (4) evaluating the liquidity of receivables accelerating, and (5) eventually cash receipts from accounts receivables' holders. He emphasises that a critical part of managing accounts receivable is determining to whom credit should be extended. This, however, is contrary to universities' policy as, without any credit screening, credit is offered to students when they register for academic courses. Credit screening involves firms requesting potential customers to provide references from banks and suppliers as a way to determine their payment history and credit profile. Consequently, South African universities have student accounts receivable in the range of millions of rands (StatsSA 2015).

The different credit management policies that South African universities implement to ensure student fee payment further contribute to the student debt problem. Credit management policies include a variety of practices, ranging from conservative to aggressive. A practical example of 
an aggressive policy is where only a short grace period is allowed for fee payment or a high percentage of deferred debt has to be paid before students are allowed to register or write exams. A conservative policy on the other hand is where longer grace periods are allowed and no or a lower percentage of deferred debt has to be paid before registration or writing exams (HESA 2008). It is crucial for the management of universities to support and drive the credit management policy. Accounts receivable management entails determining an appropriate credit management policy, examining ways to ensure prompt collections, and decreasing bad debts (Kontuš 2013). An ineffective credit management policy may negatively affect cash flow and cause the organisation to incur bad debt expenses. Michalski (2007) emphasises that credit management models need reconstruction in order to make them suitable to firms that want to maximise their value. Therefore, it is important for universities to adapt and define their credit management policies to be relevant and appropriate for their environment.

The objective of the study was to conduct an assessment of the credit management policies of the South African UOTs relative to a best (optimum) practice policy benchmark. A three-pronged approach was followed. First, the credit management policy of each UOT under consideration was assessed to determine, relative to the others, to what extent a UOT's policy is aggressive, moderate or conservative. Second, the perspective of the students of each UOT was gauged to determine to what extent the credit management policy is appropriate. Third, the research determined a best practice frontier that assesses the extent to which a UOT's credit management policy, as an institutional resource, is relevant and appropriate for its environment.

The fieldwork for this study took place early in 2017 after the \#FeesMustFall protests of 2015 and 2016. This was before 16 December 2017 when former President Jacob Zuma announced free tertiary education at the threshold of R350 000 total household income, which will be phased in over the next 3 years (Muller 2018). The importance of the study is that universities, especially in African countries and some other similar developing countries, may learn lessons from the association between credit management policies and the institutional environment.

The study was done within the conceptual scope of institutional theory, an assertion that the institutional environment can strongly influence the development of formal structures in an organisation (Scott 2005). The study adopted a parallel mixed-method research design by collecting both qualitative and quantitative data concurrently. The qualitative approach included document analysis to assess five of the six UOTs' credit management policies. The quantitative approach tested 1392 senior students' perspectives on their UOTs' credit management policies. Finally, the aim was to bring the above results together to determine each UOT's position relative to a best practice credit management frontier.

\section{Literature review}

Context of the study and the South African higher education landscape

Institutional theory became a popular and influential description for both individual and organisational action (Dacin, Goodstein \& Scott 2002). It provides valuable procedures for investigating organisation-environment associations with an emphasis on the social rules, expectations, norms and values as the sources of pressure on organisations. According to Tolbert and Zucker (1999), institutional theory is premised on the assumption that individuals are assumed to accept and follow social norms unquestioningly, without any real reflection or behavioural resistance, based on their own particular, personal interests. Scott (2005) summarises institutional theory as considering the processes through which structures, including schemes, rules, norms and routines become established as authoritative guidelines for social behaviour. Consequently, it enquires how these elements are created, diffused, accepted and modified over space and time, and how they fall into deterioration and neglect. The study was done within this context. A university's (institution's) credit management policy should be regarded as appropriate for the individuals (students). However, such a policy should also contribute to its financial sustainability through value maximisation.

Credit management policies in business firms may range from conservative to aggressive, and the advantages of the one extreme policy are more or less the disadvantages of the other extreme policy (Correia et al. 2011). These concepts are explained to ultimately conclude on the credit management policies of the South African UOTs in pursuit of a best practice policy. To illustrate, an aggressive or stringent credit policy may increase a firm's return because its goal is to reduce accounts receivable levels that result, for example, in less money that is tied up in debtors, less bad debt and fewer discounts to encourage timely payments. However, an aggressive policy may increase a firm's risk because reducing accounts receivable may relate to losing sales and customers when the firm is of the opinion that credit should not be granted to a customer. A conservative or lenient policy has the opposite risk-return outcome where the policy's goal is to increase accounts receivable to lower risks by stimulating sales, that is, to grant credit for doubtful customers. However, the return may be lower as a result of more money tied up in debtors, more bad debt and more discounts to encourage early payment. Nevertheless, as universities do not conduct credit screenings of potential students, the risk-return theory for business firms may be somewhat biased for universities. Furthermore, an aggressive policy may save universities money (and increase returns) for the same reasons as in business firms, but students may experience such an aggressive policy as rigorous, leading to rebelliousness.

The South African government has been considering free higher education for the first undergraduate degree for 
some time. This was a mandate and resolution of the African National Congress (ANC) during their 2008 Polokwane elective conference and subsequently its 2012 Mangaung conference. After some violent protest action in 2016, the former Higher Education Minister, Dr Nzimande, announced that fees for students whose families earn between R120 000 and R600 000 annual income will not increase. This is the 'missing middle' group that the National Student Financial Aid Scheme (NSFAS) refers to as 'gap' families (Dano 2015). According to Dano (2015), they are students who do not qualify for NSFAS funding or for bank loans because they are at the end of the lower middle class. On 16 December 2016, former President Jacob Zuma announced that free tertiary education under the revised NSFAS total household income threshold of R350 000 will be phased in over the next 3 years, only applicable to qualifying first-year students in 2018 (Muller 2018). However, it was not clear how the government will fund this free higher education. The idea of free higher education may lead to credit management at South African universities in future becoming less of an issue. However, this does not dilute the value of this study because student debt will still have to be managed and since it is an issue at universities internationally. Lessons can be learned about the credit management policy and students' view of their appropriateness through the lens of the institutional theory. Furthermore, although education is free in South Africa, it is not free for all.

\section{Credit management policy}

A credit management strategy is essential to optimally manage accounts receivable. For example, Wong et al. (2016) confirm that rational explanations and social encouragement could be essential credit management strategies. The latter could be used to provide credit and to convince borrowers that their transaction costs will be reasonable if the debtor complies with the credit strategy. Many South African UOTs have credit management policies, and this study explores the enforcement appropriateness. For any institution, managing accounts receivable is as important as maintaining financial health. It is crucial to impose a strategy when attempting to recover debt from delinquent accounts receivable. If the credit management policy is not imposed appropriately, it will lead to financial constraints and illiquidity.

It is imperative that organisations communicate the credit management policy to debtors so that they understand the terms and conditions of the credit agreement. Jackson (1999) constructively argues that the relationship between an organisation's policies in such areas is the key success factor. It is the management of the organisation's responsibility to communicate its policies clearly throughout the organisation. Robust policies in those areas that often come under public scrutiny and directly affect people's lives are keys. A transparent communication system that delivers improved information flow between the organisation and its accounts receivable offers improved information flows (Petroons et al. 2014).
The debt collection procedure is also part of the credit management process. According to Darko et al. (2016), recovery of outstanding debt could impose administrative costs on institutions. Such costs may include notification about existing debt and follow-up letters with additional costs for delivery to the recipient. Furthermore, the longer an account remains outstanding, the harder it is to collect. Prompt follow-up is necessary to prevent losses. According to Kumaraswamy (2016), the credit management cycle represents an average collection period and setting effective credit standards. Ngugi, Gakure and Gekara (2017) believe that strategies such as letters, phone calls and sending statements are key drivers to accounts receivables management. Various methods may be used to collect overdue accounts. A further step may be to use collection agencies, which implies that the organisation is outsourcing the responsibility of credit collection to a third party. The organisation can do this if it does not have the capacity or when the customer cannot be reached and all the means of encouraging the customer to pay have been exhausted. On accounts receivable default, some lenders have no alternative but to track repayments either through litigation or by seizure of collateral (if there is any), whereas others might employ debt collection agencies (Ssebagala 2016). Overdue accounts may be handled by collection agencies that are highly trained, experienced and have excellent negotiating skills. Legal action is a further option to manage credit risk. However, legal action costs money, sometimes even more than the amount recovered from the debtor if the action was successful (O’Neill 2008).

Jain (2015) found that the formation and operation of the debt recovery tribunals have had a significant impact in the matter of debt recovery. Legal action is likely to speed up the recovery procedure. Hamilton (2016) admits that organisations should not allow receivables to increase dramatically; there must be constant examination, and action should be taken promptly. When there are signs of default, the problem must be addressed swiftly, using different strategies such as sending invoices or hiring lawyers earlier to enforce the payment.

Organisations must introduce innovative incentive strategies to encourage prompt payment of outstanding accounts receivable. Discounts can be used to encourage prompt payment as a number of empirical studies have revealed that discount for early payment of debt increases revenue. Mungal and Garbharran (2014) attest to this and identify that customers take longer to pay back their overdue accounts if they are not offered discounts. The benefits of offering incentives to accounts receivable by granting discounts on prompt payments increase the management of the account receivable asset (Salek 2005). The benefits include increased cash flow, reduced bad debt loss and lower administrative cost in the entire revenue cycle, which improves financial sustainability. Fabbri and Klapper (2016) provide evidence that organisations must bargain with clients. They document that organisations with weak bargaining power over their 
customers are more likely to have a larger share of goods sold on credit and offer extended payment periods before imposing penalties.

Credit management has become a challenging task for most universities. A university is a non-profit organisation aimed at providing knowledge and skills to its students. However, it is imperative that a non-profit organisation remains financially sustainable for its constant continuity. Michalski (2012) observes that accounts receivable management should contribute to the realisation of basic financial purpose of a non-profit organisation, which is the most financially effective realisation of its mission. The non-profit organisation's mission realisation is more effective when it is realised in the most efficient way. It is executed with a focus on risk and uncertainty. Any change in the level of accounts receivable increases the net working capital level and influences the cost of holding and managing accounts receivable (Michalski 2012).

Credit management policies and credit management frameworks at South African UOTs need urgent remedy in terms of designing sustainable credit management policies. Indeed, the challenges facing universities are enormous, making it even more essential that each institution develops a comprehensive credit management strategy with clear guidelines. The default of student accounts can be viewed in two ways. Firstly, there is an element of late payment, which exploits the possibility of default penalty interest for late payment. Late payment implies that the university can still receive revenue from student accounts, but not promptly. Secondly, there is a defining issue of non-payment of tuition fees where the student accounts are not paid at all and the university does not receive any revenue, which may lead to sanction or suspension of studies.

\section{Research method Qualitative research}

A qualitative approach was followed to address the first aim by conducting a document analysis to assess credit management policies of the UOTs. The sample for the document analysis consisted of documents from the five selected South African UOTs. The synthesised data contained in the documents were appraised and then organised into major themes, categories and case practices. These documents comprised audited financial reports, financial agreements between the management and the student representative council (SRC), and the published statements from the UOTs' official websites regarding student account management practices. The documents are authentic, credible, accurate and representative because they were obtained from the selected UOTs' official websites or are published, audited financial reports. The documents are trustworthy communication intended to convey and disseminate the student account management processes and have been approved following due process by the management or the university council.
Data analysis is centred on systematically exploring the data for content and meaning relating to the implication for student accounts. This involved breaking down, examining, comparing, conceptualising and categorising the data for key issues and themes from the documents. Pope, Ziebland and Mays (2000) advocate that qualitative research uses analytical categories to describe and explain social phenomena. The literature review served as a basis for the formulation regarding the organising of information into categories and related meaningful emergent themes relevant in response to the research questions. Documents have been considered carefully to reflect and construct social reality and versions of events. Blaxter, Hughes and Tight (2010) validate, through a pragmatic illustration, that documentary analysis proceeds by conceptualising from each document those elements considered significant or relevant and by assembling the findings, or setting them alongside others considered to be related. Bowen (2009) affirms the configuration of document analysis in the form of a systematic procedure for reviewing or evaluating documents, both printed and electronic.

Accordingly, the documents from various UOTs were examined systematically and interpreted in order to elicit meaning, gain understanding (making sense of characteristics) and develop empirical knowledge in order to discover insights relevant to the research problem. Objectively, documents have been used for background and context to verify findings or corroborate (contradictory) evidence from quantitative results. Finally, thematic analysis uncovered the credit management policies of the UOTs.

\section{Quantitative survey}

A quantitative approach was followed to reach the second aim of testing students' perspectives on the appropriateness of their UOTs' credit management policies. A questionnaire was developed and distributed to gather data. In one of the sections of the questionnaire, 23 questions were included based on the literature review and the knowledge obtained during such literature study. (Note that this paper only covers a section from that questionnaire as exhibited in Table 3.) A methodological process of deductive reasoning was applied to empirically test the students' perception on a five-point Likert scale. The Statistics Department at the North-West University provided advice with regard to the validity of items for statistical purposes.

The fieldwork for this study took place early in 2017 after the \#FeesMustFall protests of 2015 and 2016. This was after the announcement that a higher education fees commission would probe the possibility of fee-free higher education in South Africa. The investigation involved a questionnaire survey of 1382 students at five selected UOTs in South Africa. The sample purposely excluded first-year students because they probably are inexperienced with regard to their UOTs' credit management policies and practices. Following advice from senior staff at local universities, the questionnaire was administered in hard copy across the UOTs in a controlled environment (tutorial/class time). 


\section{Data analysis}

Document analysis was used to determine the credit management policy of each UOT. In an effort to compare the UOTs, the authors evaluated each of the credit management policies relative to the other UOTs as either 'aggressive', 'moderate' or 'conservative'. To quantify the analysis, ' 1 ', ' 2 ' and ' 3 ' were attached to the above analysis, implying that the UOT with the relatively most aggressive policy has the lowest score and the UOT with the highest score has the most conservative policy.

Because the questions in the survey were random without predetermined constructs, an exploratory factor analysis (EFA) was done. Exploratory factor analysis is a statistical system that is applied to measure things that are not directly measured by forming fundamental measurements - named latent variables - without determining the extent to which the results fit a particular model (Bryman \& Cramer 2011). In this regard, EFA was used to condense the 23 questions testing the students' perceptions of their UOTs' credit management policies to a smaller number of dimensions, named factors that explain what is common among the original set of variables. An analysis of variance (ANOVA) was used to determine whether there are statistically significant differences between the students' perceptions at the different UOTs.

The third aim was to determine a best practice credit management frontier for UOTs. This final analysis combined the results of the document analysis and the survey questionnaire. In determining a best practice frontier for UOTs, the UOTs' policies were treated as a resource (input), which is appropriate from the students' perspective (output). The model selected for this study was Charnes, Cooper and Rhodes's (1978) constant return to scale, input-orientated approach of data envelopment analysis (DEA). This model is a non-parametric linear programming technique that aggregates the efficiency in a single estimate of how one input (quantification of credit management policy) is converted into multiple outputs (the appropriateness from the students' perspective, which is broken up into the number of factors that resulted from the EFA) (Avkiran 2011). Data envelopment analysis is a useful tool to evaluate performance and benchmarking against best practice; subsequently, it assumes that if a firm is capable of producing a certain output from a given set of inputs, then other firms should also be capable of doing the same to operate on the efficiency frontier (Anderson 1996). In this study the DEA measure compares each university with the best practice university, therefore providing an indication of the universities that are efficient and those that are not. The benefit is that universities who are not operating on the efficiency frontier should study the benchmark university or universities input and output levels to enable them to improve their own efficiency. Care must be taken, as in this study, if DEA is applied when a real production function does not exist; that is, when there is no clear link between how resources (input) are directly converted into the multiple outputs. In such a case, 'the meaning of efficiency as a distance to the frontier may no longer be valid. However, DEA still yields information on relative distance to the best-practices' (Cook, Tone \& Zhu 2014). Therefore, this model will be suitable to determine the relative distance from which each of the UOTs is operating from the best-practice frontier.

\section{Results and discussion Document analysis as a qualitative research method}

Thematic analysis was used to identify the four themes pertinent to the policy implications of credit management of student accounts: (1) conveyance or communication of procedures, (2) encouragement to settle debt, (3) implementation of credit management, and (4) recovery of deferred debt. The themes and operational descriptions are provided in Table 1.

\section{Conveyance or communication of procedures}

It is the UOT's responsibility to ensure that it communicates accurate, relevant and complete information regarding the student accounts credit management policy. The information should be made available so that students and their feepaying persons can be kept abreast of the status of student accounts. For the purpose of confidentiality, the UOTs' names are reserved and they will be referred to as UOT A, B, C, D and E. From the findings, it was apparent that UOTs have various ways of communicating the credit management policies of student accounts.

The information communicated to students at some UOTs is not adequate. At UOT E, for instance, the information provided on its official website indicates mainly how students should pay for the fees by the end of the academic year (banking details), failing which the account will be handed over to debt collectors. As a result of this lenient approach or weak effort, this UOT was classified as 'conservative'. Universities A and D comprehensively communicate their credit management policies and the consequences of non-compliance. This stringent approach or upright effort results in an 'aggressive' classification. The remaining two UOTs, $B$ and $C$, communicate credit management policies, but information such as available

\begin{tabular}{|c|c|c|}
\hline \multicolumn{2}{|c|}{ Theme } & \multirow{2}{*}{$\begin{array}{l}\text { Operational description } \\
\text { This theme encapsulates the manner } \\
\text { in which the credit management } \\
\text { policies are communicated to students. }\end{array}$} \\
\hline 1 & $\begin{array}{l}\text { Conveyance or communication of } \\
\text { procedures. }\end{array}$ & \\
\hline 2 & Encouragement to settle debt. & $\begin{array}{l}\text { This theme describes the credit } \\
\text { management procedures to encourage } \\
\text { prompt payment of outstanding } \\
\text { student accounts. }\end{array}$ \\
\hline 3 & $\begin{array}{l}\text { Implementation of credit } \\
\text { management. Sub-themes included } \\
\text { credit payment period, interest } \\
\text { charged, methods of payment and } \\
\text { registration fees. }\end{array}$ & $\begin{array}{l}\text { This theme includes exploring different } \\
\text { credit management policies } \\
\text { implemented at universities of } \\
\text { technology. }\end{array}$ \\
\hline 4 & $\begin{array}{l}\text { Recovery of deferred debt. Sub-themes } \\
\text { included acknowledgement of debt, } \\
\text { governing administrative issues and } \\
\text { debt collectors. }\end{array}$ & $\begin{array}{l}\text { This theme focuses on the strategies } \\
\text { that UOTs apply to recover the } \\
\text { accumulated debt from previous } \\
\text { years. }\end{array}$ \\
\hline
\end{tabular}


discounts and payment period is missing. The credit management information is conveyed to students mainly through the UOTs' official websites and student fees booklet; therefore, the completeness of the information can be evaluated based on these sources. As the authors feel that these two UOTs fall between the conservative and the aggressive ones, they were classified as 'moderate'.

\section{Encouragement to settle debt}

An organisation must devise ways to optimise payment by debtors to maximise the present value of net earnings from accounts receivable. This can be achieved by encouraging prompt payment, thereby eliminating the risk of default and costs associated with the administration of accounts receivable. The document analysis indicates that there is a varying strategy among the UOTs in the manner that they encourage students to promptly pay their accounts. Discounts can be used as an incentive to achieve early settlement of accounts receivable. Among the UOTs, UOT A offers the highest discount of $10 \%$ on tuition fees if the student account is settled by 31 March for year students. Semester 1 students have to settle their accounts by 28 February, whereas Semester 2 student accounts have to be settled by 31 August to qualify for discounts. Notably, only national students have to apply for the discount after settlement of the accounts, and then the discount will be credited to the student accounts. UOT D also offers a settlement discount of $5 \%$ on tuition fees for annual and Semester 1 registrations if accounts are settled by 28 February, whereas Semester 2 students have to settle their accounts by 31 July to qualify for the discount. For both of these UOTs, discount becomes applicable only to students paying their own fees. UOTs B, C and E do not offer any settlement discounts.

\section{Implementation of credit management}

At all the UOTs under study, students with various levels of debt are expected to make payments over and above the required minimum upfront payments. These payments have to be made during the month-long registration period at the beginning of the semester. The implementation of credit management was analysed by means of documents' analysis by examining the framework with credit payment period, interest rate charges, method of payment and registration fee payments.

Credit payment period: Universities of technologies A and D have a clear and detailed credit payment period for year courses and semester courses. The policies of both UOTs clearly state that if students do not adhere to the stipulated credit agreements, the accounts are handed over to legal collection agents. UOTs B, C and E do not explicitly communicate the credit payment period of student accounts. However, UOT B indicated that all student fees should be settled by 30 November of the year of registration. The period may be extended in exceptional cases. UOT E stipulates that fees have to be paid in full by the end of the academic year, failing which the accounts will be handed over to debt collectors. The credit payment period must be enforced appropriately by timely issuing of student statements.

Interest rate charges: Accounts receivable may increase profitability because of the implicit interest rates involved. UOTs A, C and D charge interest on overdue student accounts, whereas UOTs B and $\mathrm{E}$ do not. The interest rate charged varies among UOTs - between $5 \%$ and $7 \%$. Interest charged is debited to the student accounts.

Method of payment: All the UOTs have a cashier's office, where fees can be paid in cash or by card payments. However, UOTs B, C, D and E limit the amount of cash that may be handled on the UOT premises. University of technology $\mathrm{C}$ is actually a cashless university. All the UOTs have bank accounts into which fees can be paid by cash deposit or by cheque directly into the bank account or electronically. Postal orders and money orders are also applicable at UOTs C and D, while other UOTs do not use these facilities.

Registration (initial upfront) fees payments: The document analysis revealed that it is compulsory at all the UOTs for students to pay an initial registration fee prior to registering for the particular academic year. The registration fee varies among the UOTs. In the financial statements it is stated that the registration fee is paid to mitigate the credit risk that UOTs are exposed to from outstanding student accounts. Registration fees are based on a fixed amount approved by the UOT management, and this amount is credited to student accounts. The significance of the registration fee is based on the assumption that it will alleviate the student debt. The high registration fees translate to lower outstanding accounts receivable. Among the UOTs, the results indicate that UOT $\mathrm{B}$ charges the highest registration fee. UOT B's council did, however, approve a minimum registration fee for students who are unable to pay it. The minimum registration fee is based on the levels of family income to cater for all students.

\section{Recovery of deferred debt}

It should be noted that the contract - which forms part of the application form for admission to the UOTs - is signed by the students or their legal guardian and legally binds those parties to pay the full tuition. The UOTs have both similar and different ways in which they manage their outstanding fees. The practical recovery of deferred debt was analysed by assessing the acknowledgement of debt, regulatory or administrative governance issues and use of credit collectors.

Acknowledgement of debt: Acknowledgement of debt (AOD) is a legal agreement granted to debtors to afford them a longer period to repay the debt. The findings revealed that the UOTs require students with outstanding fees to sign an 
AOD or debt agreement before they can register or view their results. An AOD serves as an instalment plan of how the outstanding debt from the previous years will be repaid. For example, UOTs $C$ and D require students with outstanding fees who want to view their results and continue with their studies to bring their parents or legal guardian to enter into AOD arrangements with the UOT. The necessary documentation, including identity documents and proof of income, has to be provided. Unemployed persons and pensioners are not permissible as surety. Parents and legal guardians who are unable to physically visit the UOT are contacted either telephonically or by email to have the AOD forms sent to them for completion. UOT E does not reflect the payment terms of the outstanding debt. UOTs A and B have a clear policy as they require payment in proportion to the level of debt (the higher the level of debt, the higher the payment required) and students sign the payment instalment agreement for the remaining balance.

Governing administrative issues: Students with outstanding balances on their fee accounts are not permitted certain academic gratifications according to the regulatory authorities of UOTs. To be allowed to register and view their academic results, all UOTs require students with outstanding debt to settle their outstanding balance. Alternatively, they have to pay according to the AOD, plus the full registration fee. UOTs B and E do not specify whether students are allowed to graduate if they have outstanding fees. UOT C clearly stipulates that students are not permitted to graduate if they have outstanding fees. UOTs A and D permit students to graduate if they have outstanding fees if they sign an AOD. However, students are not handed the academic certificate (students are issued with the fees statement instead), but are allowed to participate in the graduation ceremony. The academic certificates at both these UOTs are withheld until after the graduation ceremony if fees are still outstanding.

Debt collectors (agencies): The results posit that all the UOTs make use of the external debt collection agencies for overdue student accounts. Notably, UOT C also hands the delinquent accounts receivable to be blacklisted, whereas UOT A clearly stipulates that student accounts are not blacklisted as a resolution of the university council. The other UOTs (B, D and E) did not disclose information on whether student accounts are blacklisted. According to SABC (2015), thousands of students have been blacklisted by universities because of outstanding university fees.

\section{Comparison of universities of technologies credit management policies}

Table 2 exhibits how the authors evaluated the credit management policies of the UOTs relative to each other on the basis of the above findings. The total score indicates the quantification of the assessment as 'aggressive', 'moderate' or 'conservative'. From this analysis, it is clear that UOT A and UOT D, with the lowest total scores, are relatively equally aggressive with their credit management policies. UOT E, with the highest score, is the most conservative, with the remaining two at different degrees of moderate. Considering the numerical values, UOTs $\mathrm{A}, \mathrm{D}$ and $\mathrm{C}$ can also rather be classified as relatively aggressive and $\mathrm{E}$ and $\mathrm{B}$ as relatively conservative.

\section{The quantitative survey}

An EFA was used to condense the number of variables to a smaller number of dimensions, named factors, to explain what is common among the original set of variables. Primarily, Bartlett's tests of sphericity and the Kaiser-MeyerOlkin (KMO) test were conducted to determine whether the data were appropriate for factor analysis. The KMO test yielded a sampling adequacy of 0.864 for students' perceptions of UOTs' credit management policy. The KMO indicators were above 0.6, implying that the data for this study are considered excellent for other EFA procedures (Kaiser 1974:35). The Bartlett's test of sphericity results for the different scales revealed significant chi-squares of $5311.397(d f=78)$ for the perceptions on credit management. All these values were at significant levels of $p=0.000 ;<0.05$, similarly asserting that factor analysis is suitable for the dataset. The item factor loading allowed was $>0.5$, as suggested by Aldlaigan and Buttle (2002).

\section{Factor extraction procedure}

In an effort to determine the number of significant measurements within the variables, the principal component analysis (PCA) was performed as recommended by Costello and Osborne (2005). Eigenvalues equal to or greater than one were examined to establish the number of factors under each

TABLE 2: Summary of document analysis and rating of the universities of technology.

\begin{tabular}{|c|c|c|c|c|c|}
\hline Themes and sub-themes & A & B & C & D & $\mathrm{E}$ \\
\hline 1. Encourage to settle debt & Aggr. & Cons. & Cons. & Mod. & Cons. \\
\hline 2. Convenience or communication of procedures & Aggr. & Mod. & Mod. & Aggr. & Cons. \\
\hline 3.1. Credit payment period & Aggr. & Mod. & Cons. & Aggr. & Mod. \\
\hline 3.2. Interest charged & Aggr. & Cons. & Aggr. & Aggr. & Cons. \\
\hline 3.3. Methods of payment & Mod. & Mod. & Aggr. & Aggr. & Mod. \\
\hline 3.4. Registration (initial upfront) fees payment & Mod. & Aggr. & Mod. & Mod. & Mod. \\
\hline 4.1. Acknowledgement of debt & Aggr. & Aggr. & Mod. & Mod. & Cons. \\
\hline 4.2. Governing administrative issues & Mod. & Cons. & Aggr. & Mod. & Cons. \\
\hline 4.3. Debt collectors (agencies) & Cons. & Mod. & Aggr. & Mod. & Mod. \\
\hline Total score (Aggr. $=1$, Mod. $=2$, Cons. $=3$ ) & 14 & 19 & 16 & 14 & 23 \\
\hline
\end{tabular}

Aggr., Aggresive; Mod., Moderate; Cons., Conservative. 
section, following Kaiser's criteria (Ledesma \& Valero-Mora 2007). From the 23 questions, only 12 questions were included in three factors as their factor loading values ranged from 0.540 to 0.878 , well above the baseline value of 0.5 . Consequently, 11 questions with very little impact were eliminated. Table 3 provides factors extracted and rotated factor loadings for students' perceptions on credit management. The question number appears on the left and the question (statement) is also provided. The mean value of each factor is also exhibited, which is the result on the fivepoint Likert scale, where ' 1 ' represents 'strongly disagree' and ' 5 ' represents 'strongly agree'.

The first factor in Table 3 was named Fairness of credit management policy. It contains five items (eigenvalue $=4.569$ ) and explained $35.150 \%$ of the total variance. This factor emphasises the students' perspective on the fairness of the credit management policies at five South African UOTs.

The second factor in Table 3 was named Familiarity of credit management policy and it entailed three items (eigenvalue = 1.445), which explained $11.118 \%$ of the total variance. The items (questions) loaded in this factor can assist to examine the efficacy of how UOTs communicate their credit management policy to relevant stakeholders. The mutual relationship with accounts receivable is crucial for the effectiveness or appropriateness of the credit management policy. This can be achieved by ensuring that the credit management policy is communicated accurately, conveying relevant and complete information.

The third factor was titled Accuracy of application of credit management policy, and contained four items (eigenvalue $=$ 1.077) and explained $8.284 \%$ of the total variance. This factor highlights the effectiveness of credit management policies at five selected South African UOTs. As discussed, credit management procedure starts with the correct and timely mailing of invoices. Credit management policy should ensure timely conversion of accounts receivable into cash to be appropriate. The students who obtain the notice letters influence this cycle by reducing their debt behaviour relative to the ones who did not receive the letters.

\section{Analysis of means}

The three factors were further analysed by ANOVAs to determine whether variables are differently answered between groups. Note that only statistically significant differences are reported. The questions (or statements) included in the factors are such that a higher mean score indicates a perception that higher education students agree to: (1) the UOTs' fairness of the credit management policy; (2) the extent to which students are familiar with the policy; and (3) the extent of the accuracy of the application of the policy, and vice versa.

Table 4 indicates that statistically significant differences were found between the five institutions in all the factors of the appropriateness of the credit management, significant at $p<0.05$. A post-hoc test was computed to examine which specific groups differed significantly.

The results of the post-hoc tests illustrated in Table 4 show that the mean scores for Factor 1 indicate that there are statistically significant differences among students' perceptions from five UOTs. For example, UOT A (mean 2.8452) has a significantly higher mean than $E$ (2.5979) and D (2.5667), whereas UOT C (mean 3.0092) has a significant higher mean than E, D and B (2.6747). The interpretation of these results is as follows:

Fairness of credit management policy (Factor 1): Students from UOTs $A$ and $C$ have a significantly more positive acceptance of their UOTs' credit management policy than E, D and B.

Familiarity of credit management policy (Factor 2): Students from UOTs A, C, D and B have a significantly better understanding of their UOTs' credit management policy than students of

TABLE 3: Factors for students' perception on appropriateness credit management policy.

\begin{tabular}{|c|c|c|c|c|}
\hline No. & Student's perceptions & $\mathbf{F 1}$ & F2 & F3 \\
\hline \multicolumn{5}{|c|}{ Factor 1: Fairness of credit management policy } \\
\hline 6 & The fees payment policy accommodates students from disadvantaged backgrounds & 0.752 & - & - \\
\hline 7 & I comply with the stipulated university credit management policy & 0.668 & - & - \\
\hline 23 & Upfront payment that is charged by the university is affordable & 0.625 & - & - \\
\hline 4 & I am satisfied with the current credit management policy on student accounts at my university & 0.590 & - & - \\
\hline 12 & The credit management policy at my university encourages students to settle student debts promptly & 0.540 & - & - \\
\hline \multicolumn{5}{|c|}{ Factor 2: Familiarity of credit management policy } \\
\hline 2 & I have read the fees payment policy towards student accounts at my university & - & 0.878 & - \\
\hline 1 & I know student credit management policy at my university & - & 0.833 & - \\
\hline 3 & The fees payment policy at my university is easily understandable & - & 0.758 & - \\
\hline \multicolumn{5}{|c|}{ Factor 3: Accuracy of application of credit management policy } \\
\hline 15 & The student fees statement indicates the dates when fees should be paid & - & - & 0.694 \\
\hline 14 & The student fees statement I receive from the university reflects the correct amounts and balances & - & - & 0.690 \\
\hline 16 & It is the policy that my university grants merit bursaries for academic achievements & - & - & 0.600 \\
\hline
\end{tabular}

F1: Mean $=2.772 ;$ Eigenvalue $=4.569 ; \%$ of variance explained $=35.150 ;$ Cumulative variance explained $=35.150 ;$ Cronbach's alpha $=0.748$

F2: Mean $=2.760 ;$ Eigenvalue $=1.445 ; \%$ of variance explained $=11.118 ;$ Cumulative variance explained $=46.268 ;$ Cronbach's alpha $=0.821$

F3: Mean $=3.123 ;$ Eigenvalue $=1.077 ; \%$ of variance explained $=8.284 ;$ Cumulative variance explained $=54.552 ;$ Cronbach's alpha $=0.625$ 
TABLE 4: Post-hoc test: Dimensions of students' perceptions on credit management policy. Appropriateness of credit management policy.

\begin{tabular}{|c|c|c|c|c|c|c|c|}
\hline Dependent variable & University & $N$ & Mean & University & $N$ & Mean & Mean difference \\
\hline \multirow{5}{*}{$\begin{array}{l}\text { Factor 1: } \\
\text { Fairness }\end{array}$} & \multirow[t]{3}{*}{ C } & \multirow[t]{3}{*}{369} & \multirow[t]{3}{*}{3.0092} & D & 252 & 2.5667 & 0.4425 \\
\hline & & & & E & 195 & 2.5979 & 0.4113 \\
\hline & & & & B & 265 & 2.6747 & 0.3345 \\
\hline & \multirow[t]{2}{*}{$A$} & \multirow[t]{2}{*}{301} & \multirow[t]{2}{*}{2.8452} & D & 252 & 2.5667 & 0.2785 \\
\hline & & & & $\mathrm{E}$ & 195 & 2.5979 & 0.2473 \\
\hline \multirow{5}{*}{$\begin{array}{l}\text { Factor 2: } \\
\text { Familiarity }\end{array}$} & $A$ & 301 & 2.9435 & E & 195 & 2.2855 & 0.6580 \\
\hline & \multirow[t]{2}{*}{ C } & \multirow[t]{2}{*}{369} & \multirow[t]{2}{*}{2.8979} & E & 195 & 2.2855 & 0.6124 \\
\hline & & & & B & 265 & 2.6403 & 0.2576 \\
\hline & D & 252 & 2.8360 & E & 195 & 2.2855 & 0.5505 \\
\hline & B & 265 & 2.6403 & E & 195 & 2.2855 & 0.3548 \\
\hline \multirow{3}{*}{$\begin{array}{l}\text { Factor 3: } \\
\text { Accuracy }\end{array}$} & \multirow[t]{3}{*}{ C } & \multirow[t]{3}{*}{369} & \multirow[t]{3}{*}{3.3455} & $E$ & 195 & 2.8231 & 0.5224 \\
\hline & & & & D & 252 & 3.0050 & 0.3405 \\
\hline & & & & A & 301 & 3.0872 & 0.2583 \\
\hline
\end{tabular}

Note: The mean difference is significant at the 0.05 level. (Note that only ANOVAs were included and discussed where significant differences were found. For example, Factor 1's mean score is not significantly different for $\mathrm{C}$ and $\mathrm{A}$.)

UOT E. Furthermore, students of UOTs A and C have a significantly better understanding than students of UOT B.

Accuracy of application of credit management policy (Factor 3): Students from UOTs C and B experience a significantly higher degree of precision of their UOTs' credit management than UOTs A, D, and E.

It is imperative that there are inherent differences in the implementation of credit management policies at South African UOTs. These findings can assist in understanding how students respond to the appropriateness of these policies at various UOTs.

\section{Comparison of the qualitative and quantitative results}

Table 5 presents a summary of the inputs and outputs necessary to determine information on the relative distance that each UOT is operating from the best practice frontier. The input variable is the quantification of the credit management policy (Table 2), where a lower score indicates a more aggressive policy and a higher score a more conservative policy. The output variable is represented by the mean score of students' perspective with regard to the appropriateness of their UOTs' credit management policy, broken up into three factors as per the factor analysis (Table 4). Note that the higher the mean score, the more appropriate the policy is from the students' perspective.

As mentioned earlier, the risk-return theory in business firms is somewhat biased for universities because they do not determine a credit screening for prospective students with credit automatically offered when they enrol. Therefore, we maintain that universities should, from a financial management view, rather use an aggressive credit management policy that has the advantage that, in theory, it has a higher return relative to a conservative policy. Furthermore, the financial disadvantage of an aggressive
TABLE 5: Quantification of credit management policies and students' perspective.

\begin{tabular}{lccccc} 
Variable & Input & & \multicolumn{3}{c}{ Output: Factors of appropriateness of policy } \\
\cline { 2 - 2 } \cline { 5 - 6 } & Policy as resource & & Fairness & Familiarity & Accuracy \\
\hline A & 14 & & 2.8452 & 2.9435 & 3.0872 \\
B & 19 & & 2.6747 & 2.6403 & 3.1858 \\
C & 16 & & 3.0092 & 2.8979 & 3.3455 \\
D & 14 & & 2.5667 & 2.8360 & 3.0050 \\
E & 23 & & 2.5979 & 2.2855 & 2.8231 \\
\hline
\end{tabular}

policy is not valid for universities, that is, the risk that a customer or sale will be lost as a result of a stringent credit granting policy. From a financial management view, a conservative policy is a poor choice because, in theory, the disadvantage is that the return is relatively lower than an aggressive policy, but the advantage of such a policy does not realise, that is, customer or sale will not be lost as a result of the lenient credit granting policy. This argument leads to the conclusion that an aggressive policy has the advantage of a higher return with no disadvantage of losing students, whereas a conservative policy has the disadvantage of a lower return with no advantage of obtaining students.

With this as background, we decided to attach a lower score as the aggressiveness increases. This is to calculate an efficiency frontier, which is based on the principle of minimum-input-maximum-output. Therefore, the efficiency estimate from the DEA mathematics will show at least one UOT as fully efficient and operating at the efficiency frontier, with an estimate of 1 . For the other UOTs, the closer the estimate is to 1 , the closer they operate on the best practice frontier.

The software purposely built by Zhu (2009) was used to calculate input-orientated constant return to scale 'efficiency' estimate, indicating each university's relative distance from the best practice frontier. Note that the numbers of five data points are regarded as sufficient because the aim was not to determine which of the variables are significant, which would have required high quantitative numbers. However, 
TABLE 6: Efficiency estimates: Distance from best practice frontier

\begin{tabular}{lcccc}
\hline Variable & $\begin{array}{c}\text { Aggregated } \\
\text { 'efficiency' }\end{array}$ & \multicolumn{3}{c}{ 'Efficiency' per factor } \\
\cline { 2 - 5 } & 1.000 & 1.000 & 1.000 & Accuracy \\
\hline A & 0.760 & 0.693 & 0.661 & 0.760 \\
B & 0.948 & 0.925 & 0.861 & 0.948 \\
C & 0.973 & 0.902 & 0.963 & 0.973 \\
D & 0.556 & 0.556 & 0.472 & 0.556 \\
E & & & &
\end{tabular}

the DEA approach was only used to position each of the five UOTs mathematically relative to the others.

Table 6 indicates in the aggregated efficiency column that UOT A is relatively fully 'efficient' with an efficiency estimate of 1. (The aggregated efficiency is where the single input and three output variables were included.) Therefore, it is currently operating on the best practice frontier, that is, with their credit management policy as resource, this is the most appropriate from the students' perspective. UOT A is also the benchmark for all the other UOTs, whereas UOT E (.557) and UOT B (.760) are some distance from the best practice frontier, implying that they should increase their output variable by $44.3 \%$ and $24 \%$ respectively if they want to operate on the efficiency frontier. Alternatively, there may also be a decrease in their input variables with the corresponding percentages. UOTs C and $\mathrm{D}$ are relatively close to best practices and only need some minor input or output changes. The efficiency was also calculated where the input variable is the quantification of the credit management policy and the output variables are alternately the three factors of appropriateness. Similar patterns are shown as in the case of the aggregated estimate with the three outputs. (Note that the aggregated efficiency estimate is similar to the estimate in the last column, Accuracy. This is the result of the limited number of UOTs and that the model is non-parametric, using ranking orders.)

\section{Conclusion}

The objective of the study was to perform an assessment of the credit management policies of the South African UOTs relative to a best practice policy. Consequently, the credit management policy of each UOT under consideration was first assessed. It was found that three of the five UOTs (A, D and $C$ ) have relatively aggressive credit management policies, whereas two (E and B) have relatively conservative policies. Secondly, the perspectives of the students of each UOT were analysed to determine to which extent the credit management policy is appropriate. The study found that the 'appropriateness' can be refined into three factors, that is, fairness, familiarity and accuracy of the application of the credit management policy. This assisted the study to do further analyses, which revealed that the different factors are differently rated per UOT. UOTs $\mathrm{A}$ and $\mathrm{C}$ are rated significantly higher than the others for fairness. UOT E's students, and to a lesser extent UOT B's students, are significantly less familiar with their UOTs' credit management policies than the others, and UOTs C and B are significantly more precise or accurate in the application of their credit management policy. Thirdly, a best practice frontier, which assesses the extent to which a UOT's credit management policy as an institutional resource is appropriate for its environment, was calculated. The finding was that UOT A, which was labelled relatively aggressive, was fully efficient, operating on the best practice frontier and serving as a benchmark for the others, whereas UOTs C and D, which were also labelled relatively aggressive, are relatively close to the best practice frontier, but UOTs E and B, which were labelled as relatively conservative, operate at some distance from the best practice frontier.

\section{Recommendation}

It is recommended that the UOTs not operating on the best practice frontier, especially UOTs E and B, should move to a more aggressive policy (lower their input score) or get a higher appropriateness rating from the students (increase the output score). It can be argued that the more aggressive the credit management policy is, the higher it is rated pertaining to appropriateness granted by the students, and vice versa. Contrary to literature, no evidence was found that a stringent or aggressive policy may be experienced as rigorous.

It is evident how the institutional environment influences the development of formal structures; that is, students desire that the credit management policy: (1) is communicated to them clearly so that they can obtain a sound understanding; (2) encourages them, by granting discounts, to do early settlements of debt; (3) is strictly implemented; and (4) is strict with regard to the collection and recovery of (deferred) debt. This finding contributes to the extant literature. It is evident that the UOTs should: (1) make a concerted effort to communicate the policy and to encourage timely debt settlements; and (2) ensure their policy is not lenient, but stringent. This will result in an appropriate policy for the environment that students perceive as fair, understandable and accurate.

The shortcoming of this study is that it did not investigate the effect of the different UOTs' policies on their financial performance. Further studies should focus on this to determine whether an aggressive credit management policy is more likely to lead to an improved financial performance, and vice versa.

\section{Acknowledgements}

Please note that this article will also be presented at the Southern African Accounting Association (SAAA) conference, June 2019 at Emperors Palace, Johannesburg. This submission to SAAA is a 'track 3' submission, implying that this paper will not be part of SAAA's review process, neither it will be included in their conference proceedings.

\section{Competing interests}

The authors declare that they have no financial or personal relationships that may have inappropriately influenced them in writing this article. 


\section{Authors' contributions}

The content of this article was extracted from the PhD of G.J.M., on whom the degree was conferred in 2018. M.O. was the promoter of the $\mathrm{PhD}$ study and did some additional analysis and drafted the article. S.L.M. was the co-promoter of the PhD study and assisted with the final draft and approved the final version.

\section{Ethical considerations}

The five universities that were investigated in this study each provided a clearance letter to continue with the study. However, only two added numbers: REC/2016/08/06 (Tshwane University of Technology) and ECN43-2017 (Vaal University of Technology). The university where the study was registered provided the number: NWU-0001-13-A1 (North-West University). Ethics clearance certificates were obtained from each UOT under review.

\section{Funding}

This research received no specific grant from any funding agency in the public, commercial or not-for-profit sectors

\section{Data availability statement}

Data sharing is not applicable to this article as no new data were created or analysed in this study

\section{Disclaimer}

The views and opinions expressed in this article are those of the authors and do not necessarily reflect the official policy or position of any affiliated agency of the authors

\section{References}

Aldlaigan, A.H. \& Buttle, F.A., 2002, 'SYSTRA-SQ: A new measure of bank service quality', International Journal of Service Industry Management 13(4), 362-381. https://doi.org/10.1108/09564230210445041

Anderson, T., 1996, A data envelopment analysis (DEA) Homepage, viewed n.d., from http://www.emp.pdx.edu.dea/homedea.html/.

Avkiran, N.K., 2011, 'Association of DEA super-efficiency estimates with financial ratios: Investigating the case for Chinese banks', Omega 39(3), 323-334. https:// ratios: Investigating the case for

Blaxter, L., Hughes, C. \& Tight, M., 2010, How to research, McGraw-Hill/ Open University Press, Maidenhead.

Bowen, G.A., 2009, 'Document analysis as a qualitative research method', Qualitative Research Journal 9(2), 27-40. https://doi.org/10.3316/QRJ0902027

Bryman, A. \& Cramer, D., 2011, Quantitative data analysis with IBM SPSS 17, 18 and 19. A guide to social scientists, Routledge, London.

Charnes, A., Cooper, W.W. \& Rhodes, E., 1978, 'Measuring efficiency of decisionmaking units', European Journal of Operations Research 2, 429-444. https://doi. org/10.1016/0377-2217(78)90138-8

Cook, W.D., Tone, K. \& Zhu, J., 2014, 'Data envelopment analysis: Prior to choosing a model', Omega 44, 1-4. https://doi.org/10.1016/j.omega.2013.09.004

Correia, C., Flynn, D., Uliana, E. \& Wormald, M., 2011, Financial management, Juta, Cape Town.

Costello, A.B. \& Osborne, J.W., 2005, 'Best practices in exploratory factor analysis: Four recommendations for getting the most from your analysis', Practical Assessment, Research \& Evaluation 10(7), 1-9.

Dacin, M.T., Goodstein, J. \& Scott, W.R. 2002. 'Institutional theory and institutional change: Introduction to the special research forum', Academy of Management Journal 45(1), 45-56. https://doi.org/10.5465/amj.2002.6283388
Dano, Z., 2015, 'Not poor enough for student financial aid', Cape Argus, 02 November, viewed n.d. from https://www.iol.co.za/news/south-africa/western-cape/notpoor-enough-for-nsfas-1939014.

Darko, E.A., Adarkwah, S., Donkor, F. \& Kyei, E., 2016, 'Management of accounts receivables in utility companies: A focus on Electricity Company of Ghana (ECG)', International Journal of Academic Research in Business and Social Sciences 6(11), 486-518. https://doi.org/10.6007/IJARBSS/v6-i11/2422

Fabbri, D. \& Klapper, L.F., 2016, 'Bargaining power and trade credit', Journal of Corporate Finance 41, 66-80. https://doi.org/10.1016/j.jcorpfin.2016.07.001

Hamilton, M., 2016, 'Wine law: Effective debt collection for wineries', Australian and New Zealand Grapegrower and Winemaker 630, 65.

Higher Education South Africa (HESA), 2008, Tuition fees: higher education institutions in South Africa, Pretoria, viewed n.d., from http://www.hesa.org.za/resources/ HESA $\% 20$ TT $\% 20$ Report $\% 20 \% 20-\% 2017 \%$ Feb $\% 202008 \% 20$ (20).pdf.

Jackson, T., 1999, 'Managing change in South Africa: developing people and organizations', International Journal of Human Resource Management 10(2), 306-326. https://doi.org/10.1080/095851999340576

Jain, S., 2015. Recovery of debts due to banks and financial institutions: Lega framework in India, viewed n.d., from https://ssrn.com/abstract $=2808408$ or https://doi.org/10.2139/ssrn.2808408

Kaiser, H.F., 1974, 'An index of factorial simplicity', Psychometrika 39(1), 31-36. https://doi.org/10.2139/ssrn.2808408

Kontuš, E., 2013, 'Management of accounts receivable in a company', Ekonomska misao i praksa 1, 21-38.

Kumaraswamy, S., 2016, 'Impact of working capital on financial performance of Gulf Cooperation Council firms', International Journal of Economics and Financial Issues 6(3), 1136-1142.

Ledesma, R.D. \& Valero-Mora, P., 2007, 'Determining the number of factors to retain in EFA: An easy-to-use computer program for carrying out parallel analysis', Practical Assessment, Research \& Evaluation 12(2), 1-11.

Michalski, G., 2007. 'Portfolio management approach in trade credit decision making', Romanian Journal of Economic Forecasting 8(3), 42-53.

Michalski, G., 2012, 'Financial liquidity management in relation to risk sensitivity: Polish firms case', in Proceedings of the International Conference quantitative methods in economics (Multiple criteria decision making Xvi), pp. 141-160.

Muller, S.M., 2018. 'Free higher education in South Africa: Cutting through the lies and statistics', Mail \& Guardian, 25 January, viewed n.d., from https://mg.co.za/ article/2018-01-25-free-higher-education-in-south-africa-cutting-through-the-liesand-statistics.

Mungal, A. \& Garbharran, H.L., 2014, 'Cash management challenges of small businesses in a developing community' Mediterranean Journal of Social Sciences 5(27), 11-21. https://doi.org/10.5901/mjss.2014.v5n27p11

Ngugi, S.K., 2015, 'Determinants of accounts receivables management in the hote industry in Kenya', Doctoral dissertation, Nairobi, Jomo Kenyatta University of Agriculture and Technology.

Ngugi, S.K., Gakure, R.W. \& Gekara, G.M., 2017, 'Effects of organization size on accounts receivable management in the hotel industry in Kenya', American Journal of Accounting 1(1), 24-46.

O'Neill, P.G., 2008, Method to improve debt collection practices, Accenture Globa Services GmbH, U.S. Patent 7,401,050.

Petroons, J., Hanan, C.C., Bailey, A.G., Gupta, S.D., Mellyn, K.L., Saal, M. et al., 2014, JPMorgan Chase Bank \& NA, Electronic multiparty accounts receivable and accounts payable system, U.S. Patent $8,712,887$.

Pope, C., Ziebland, S. \& Mays, N., 2000, 'Analysing qualitative data', British Medical Journal 320(7227), 114. https://doi.org/10.1136/bmj.320.7227.114

Ramiah, V., Zhao, Y., Moosa, I. \& Graham, M., 2016, 'A behavioural finance approach to working capital management', The European Journal of Finance 22(8-9), 662-687. https://doi.org/10.1080/1351847X.2014.883549

SABC, 2015, Thousands of university students blacklisted due to unpaid fees, viewed n.d., from http://www.sabc.co.za/news/a/c316a2004772b76f8060e642d945d4b0/ Thousands-of-university-students-blacklisted-due-to-unpaid-fees--20150226.

Scott, W.R., 2005, 'Institutional theory: Contributing to a theoretical research program', Great minds in management: The process of theory development 37, 460-484.

Salek, J.G., 2005, Accounts receivable management best practices, John Wiley, NJ.

Ssebagala, R. 2016, Relieving consumer over-indebtedness: The need for a 'fresh start' in South Africa, Centre for Social Science Research, Working Paper 369, University of Cape Town.

Statistics South Africa, 2015, Financial statistics of higher education institutions, viewed from www.statssa.gov.za.

Tolbert, P.S. \& Zucker, L.G., 1999, 'The institutionalization of institutional theory', in Studying organization. Theory \& method, pp. 169-184, London.

Wong, A., Lu, W., Tjosvold, D. \& Yang, J., 2016. 'Extending credit to small and medium size companies: Relationships and conflict management', International Journal of Conflict Management 27(3), 331-352. https://doi.org/10.1108/ IJCMA-06-2015-0034

Zhu, J., 2009, Quantitative models for performance evaluation and benchmarking Data envelopment with spreadsheets and DEA Excel Solver, Springer, New York. 